\title{
Sharks in nearshore environments: models, importance, and consequences
}

\author{
Danielle M. Knip ${ }^{1, *}$, Michelle R. Heupel ${ }^{2}$, Colin A. Simpfendorfer ${ }^{1}$ \\ ${ }^{1}$ Fishing and Fisheries Research Centre, School of Earth and Environmental Sciences, James Cook University, Townsville, \\ Queensland, 4811, Australia \\ ${ }^{2}$ School of Earth and Environmental Sciences, James Cook University, Townsville, Queensland, 4811, Australia
}

\begin{abstract}
Theoretical models of coastal shark populations have remained largely unchanged since the 1960s despite limitations in applicability to many species. Smaller bodied coastal species are poorly represented by the current models. A new theoretical model is proposed to represent those species that spend most or all of their life within nearshore waters but do not show use of discrete nursery areas. Description of this new model outlines the importance of nearshore areas to these smaller species. While all coastal shark populations are susceptible to environmental and anthropogenic impacts, species that fit the new model are more vulnerable to varying coastal processes, habitat degradation, and fishing pressure than are species that use nearshore areas for only part of their life-span. The dynamic nature of nearshore areas and their proximity to human populations present all sharks that occur in them with a range of advantages and disadvantages. This paper reviews how different species utilise nearshore areas and how they overcome the challenges they face in inhabiting these areas. Improving and expanding theoretical models of coastal shark populations will provide a better understanding of how sharks use nearshore environments and assist in making conservation and management decisions for these regions.
\end{abstract}

KEY WORDS: Nearshore - Shark - Population model · Habitat use · Distribution · Springer

Resale or republication not permitted without written consent of the publisher

\section{INTRODUCTION}

Nearshore areas typically consist of shallow water with temporally varying characteristics and are commonly comprised of highly dynamic ecosystems supporting high biodiversity (Robertson \& Duke 1987,

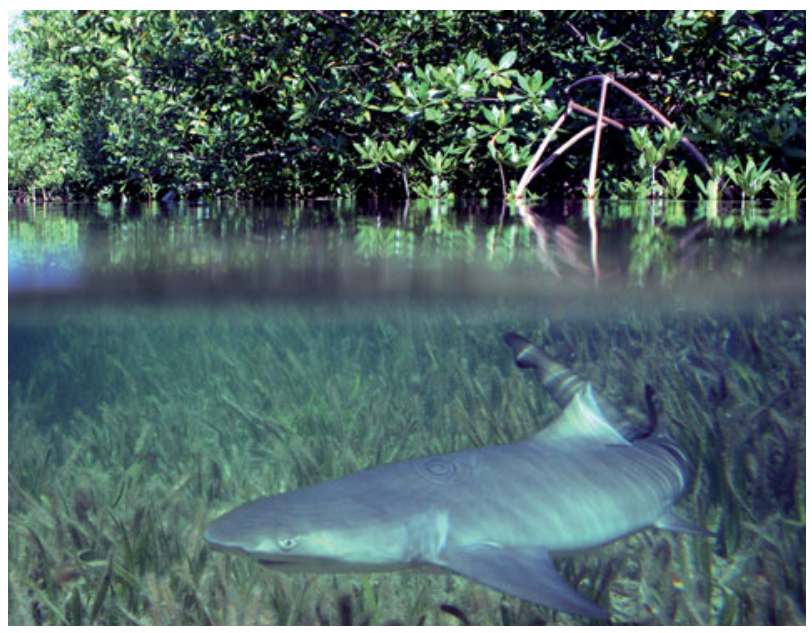

Population models show that nearshore habitats are crucial for small coastal sharks such as juvenile lemon sharks Negaprion brevirostris.

Photo: Alastair Harry

Morin et al. 1992). Major fluctuations in salinity, temperature, depth, flow, and turbidity occur in nearshore waters on a variety of temporal scales (from hours to seasons) due to changes in tidal level, freshwater flow, rainfall, and seasonal weather patterns (Mann 2000, Masselink et al. 2008). Although variable conditions may create challenging environments for inhabitants, nearshore areas are highly productive and have a relatively high abundance and a rich diversity of fish and invertebrate species (Blaber et al. 1989, Beck et al. 2001). As a result of high productivity, nearshore waters have considerable economic value supporting recreational, commercial, and indigenous fisheries. Overall, nearshore areas contribute goods and services 
of high quantity and quality to both environment and economy, resulting in these areas being identified as significantly valuable ecosystems (Costanza et al. 1997).

Close proximity to land allows easy accessibility to nearshore areas, resulting in these regions being susceptible to increased exploitation. Fishing is one of the major human impacts affecting nearshore waters and overfishing has resulted in the decline and/or collapse of some coastal ecosystems (Pauly et al. 1998, Jackson et al. 2001). Coastal development also has detrimental effects on nearshore areas through modification practices such as dredging, construction, and deforestation, which can cause large-scale habitat degradation or loss (Suchanek 1994, Vitousek et al. 1997). The estimated proportion of the world's total human population living within $100 \mathrm{~km}$ of the coast is $60 \%$ (Vitousek et al. 1997), with this value projected to be $75 \%$ within $60 \mathrm{~km}$ of the coast by the year 2020 (DeMaster et al. 2001). Due to increasing human population in coastal areas, it is likely that human pressure in these regions will continue and potentially increase. With increased pressure, it will be progressively more important to understand how species and communities use nearshore waters so that effective conservation and management can be implemented. In addition to anthropogenic influences, environmental impacts such as weather events result in erosion, scouring, habitat destruction, sediment movement, and increased turbidity in nearshore areas (Rodriguez et al. 1994, Masselink et al. 2008). Inter-annual climate anomalies (e.g. El Niño, La Niña, drought) can change the physical characteristics of nearshore environments making conditions less favourable for inhabitants (Mol et al. 2000, Abel et al. 2007). Since nearshore areas are highly dynamic and variable, as well as vulnerable to exploitation, species that inhabit these waters must either cope with the changes they face, adapt accordingly, or leave in order to survive.

Sharks are a key component of nearshore ecosystems, acting as top predators and utilising a high proportion of available energy (Cortés 1999). Since nearshore waters provide a wide variety of habitat characteristics, sharks can exploit regions with features that are optimal for survival. For example, young sharks may utilise shallow or low salinity environments to decrease predation risk (Simpfendorfer et al. 2005, Wetherbee et al. 2007) or to forage in areas where food resources are most abundant (Simpfendorfer \& Milward 1993); adults may exploit habitats to target high quality prey items for diet and growth (Heithaus et al. 2002). Nearshore regions are also used in different ways by different shark species, and the characteristics and habitat type of a region may influence species distribution and movement (White \& Potter 2004,
DeAngelis et al. 2008). Thus, habitat use by sharks within nearshore areas is likely to be influenced by a combination of ecological factors including environmental characteristics, resource abundance and distribution, and/or presence of other competing species.

Common nearshore shark species consist primarily of carcharhinids and sphyrnids in tropical and subtropical regions, and triakids in temperate regions (Bigelow \& Schroeder 1948, Compagno 1984, Last \& Stevens 2009). Species from these groups tend to be well studied because they are encountered often in coastal regions and are easily captured. These groups also form the basis of some important fisheries, which has further driven research (Grace \& Henwood 1997, Francis 1998, Walker 1998, Pradervand et al. 2007). However, the diversity of sharks that occur in nearshore waters is much greater than these 3 families alone (e.g. scyliorhinids, orectolobids, ginglymostomatids, heterodontids). It is important to recognise the diversity of sharks within nearshore areas because different species behave in different ways (Bethea et al. 2004), have different life-histories (Cortés 2000) and, as top predators, may have a large influence on nearshore community dynamics (Heithaus et al. 2008).

Although the species composition of sharks that occur in nearshore waters is diverse, descriptions of distribution and habitat use tend to be generalised. For example, a theoretical model proposed by Springer (1967) broadly outlined the geographic range and distribution of a hypothetical population of sharks. In this population, young are born in nearshore nursery areas in spring/summer, where they remain until they reach sexual maturity and join the adult population further offshore. Adults occur offshore, segregated from the young except when they move inshore to give birth and mate in spring/summer. However, not all populations of sharks that occur in nearshore areas fit this model. The strategy a species utilises is shaped by both its life-history characteristics (Branstetter 1990) and surrounding environment (Sims 2003) to maximise survival, which results in distribution and habitat use varying greatly between species. Opposed to Springer's hypothetical population, a combination of life-stages may be present in nearshore regions, with species using patterns that will enhance population success.

Understanding differences in distribution and habitat use between shark species that utilise nearshore areas will help effectively conserve important habitats and the populations that use them. This review paper outlines and discusses (1) theoretical models of shark populations in nearshore areas, (2) how sharks utilise nearshore areas, and (3) challenges and potential consequences sharks face by inhabiting nearshore waters. By discussing how shark species use nearshore regions and identifying differences in species behaviour, this 
paper will present a second population model and some exceptions to Springer's theoretical population. For the purpose of this review paper, discussion will be limited to sharks and will not include skate or ray species; the term 'nearshore' will refer to all waters immediately adjacent to the coast down to a depth of $20 \mathrm{~m}$, including intertidal areas, bays, lagoons, and estuaries.

\section{THEORETICAL MODELS OF SHARK POPULATIONS IN NEARSHORE ENVIRONMENTS}

The hypothetical population introduced by Springer (1967) represents the distribution and habitat use of some common carcharhinoid shark species including blacktip Carcharhinus limbatus, sandbar Carcharhinus plumbeus, scalloped hammerhead Sphyrna lewini, and lemon Negaprion brevirostris sharks. Young of these species are usually found in warm, shallow nearshore waters during the spring and summer months, which many authors have attributed to nursery area use (e.g. Castro 1993, Heupel \& Hueter 2001, Merson \& Pratt 2001, Carlson 2002). Adults of these species are encountered much less frequently in nearshore areas, but females may move inshore during the summer months when ready to give birth (e.g. Springer 1950, 1960, Klimley 1987, Castro 1996). Nursery areas for aquatic species have been defined as regions where juveniles occur in higher densities, receive increased protection from predators, and grow at faster rates, all of which increases recruitment into the adult population (Beck et al. 2001). More specifically for shark species, nursery areas have been identified; these are not only areas where juveniles occur in higher densities, but are also areas which juveniles inhabit for long periods of time and which pupping females utilise over many years (Heupel et al. 2007). For species representative of Springer's model population, juveniles remain within nursery areas for extended lengths of time while using restricted areas of space and displaying high degrees of site attachment to nearshore habitat (e.g. Morrissey \& Gruber 1993a, Merson \& Pratt 2001, Heupel et al. 2004, DeAngelis et al. 2008). Seasonal variation may occur in spatial distribution, and individuals of some species migrate to over-wintering grounds when water temperature begins to cool in the autumn months (Castro 1996, Conrath \& Musick 2008). Although Springer's description is accurate, particularly for many large carcharhinoid species of the east coast of the USA, it only encompasses some coastal species. Species displaying Springer's hypothetical pattern generally reach a large maximum size, and have slow growth rates and long life-expectancies.

We propose a second theoretical model to encompass smaller bodied species such as Atlantic sharpnose
Rhizoprionodon terraenovae, Australian sharpnose Rhizoprionodon taylori, bonnethead Sphyrna tiburo, and blacknose Carcharhinus acronotus sharks. These species can occur in nearshore waters for the duration of their life-span, with immature and mature individuals of both sexes utilising the same regions and habitats (e.g. Simpfendorfer \& Milward 1993, Parsons \& Hoffmayer 2005, Heupel et al. 2006, Ulrich et al. 2007). Species that fit this model include both those that use restricted portions of nearshore areas (e.g. lesser spotted dogfish Scyliorhinus canicula; Sims et al. 2001), and those that are less reliant on specific areas and move farther distances throughout the nearshore environment (e.g. R. terraenovae; Carlson et al. 2008). Early life-stages of these species do not appear to use discrete nursery areas (Parsons \& Hoffmayer 2005, Heupel et al. 2006, Ulrich et al. 2007), but may roam considerable distances and utilise large amounts of space. For example, Carlson et al. (2008) reported that juvenile $R$. terraenovae had wide-ranging movements (e.g. $399 \mathrm{~km}$ ), did not remain within any specific area for significant lengths of time, and often moved through deep water. Young individuals of these species may display some site attachment and return to specific nearshore areas (Hueter et al. 2005), but such patterns are not as evident and are reported less often in these species than in those fitting Springer's model. Despite limited attachment to one particular area, species that represent this second population model may be more dependent on nearshore regions since they utilise these areas for their entire life-cycle. However, because these species often appear less reliant on specific habitat and move widely throughout nearshore areas, they may be less vulnerable to localised impacts.

It is important to note that not all nearshore shark populations fit within the 2 population models above, and exceptions can be found where different types of distribution and habitat use are utilised. For example, juveniles of some species occur further from shore and/or at greater depths than adults. Young sandbar sharks Carcharhinus plumbeus in Western Australia have been reported to inhabit deep water offshore, whereas adults occupied areas that were closer to shore (McAuley et al. 2007). This population, as well as a population of $C$. plumbeus in Hawaii, does not appear to use discrete nursery areas (McElroy et al. 2006, McAuley et al. 2007). This pattern is opposite to that displayed by $C$. plumbeus in the northwest Atlantic, where the smallest and youngest individuals inhabit shallow areas closest to shore as described by Springer. Some reef shark populations also demonstrate a lack of nearshore nursery area use. In Hawaii, juvenile Galapagos sharks Carcharhinus galapagensis do not utilise shallow nursery areas, and were reported to occur at greater depths than sub-adult and adult 
female individuals (Wetherbee et al. 1996). In Belize, the smallest Caribbean reef sharks Carcharhinus perezi were found to inhabit the deepest available habitat and did not utilise shallow regions (Pikitch et al. 2005). It has historically been assumed that shallow nearshore waters offer greatest protection from predators and increased survival for young sharks. However, different regions may require different strategies for a population to thrive; the habitat type and/or physical characteristics of an environment could influence distribution and behaviour patterns. For example, the coastline in Western Australia lacks the major estuarine systems found in nearshore areas of the northwest Atlantic (e.g. Chesapeake and Delaware Bay, USA), which young $C$. plumbeus in those regions utilise as nursery areas (Wetherbee et al. 2001, Grubbs et al. 2007). Thus, habitat and resource requirements for young $C$. plumbeus that can be obtained in nearshore environments in the northwest Atlantic may be located elsewhere in Western Australia (i.e. offshore). Therefore, distribution and habitat use by sharks in nearshore areas may be a function of the ecological characteristics specific to the environment, combined with resource needs and life-history characteristics. Given variations in distribution and habitat use, the 2 models proposed cannot describe all species of shark, but they do provide a generalised concept that will encompass many shark populations in nearshore waters.

Regional differences in distribution, habitat use, and movement occur among shark species, and populations may show plasticity in behaviour to cope in different regions. Using lemon sharks Negaprion brevirostris as an example, it is clear that differences exist among populations in different locations. Young $N$. brevirostris utilising nearshore nursery areas in the Bahamas displayed a preference for warm water $\left(30^{\circ} \mathrm{C}\right.$; Morrissey \& Gruber 1993b), while a nearshore nursery area in southeast USA showed the highest abundance of young $N$. brevirostris to occur in winter when water was cooler $\left(18-22^{\circ} \mathrm{C}\right.$; Reyier et al. 2008). Inhabiting cooler water may act as a refuge by decreasing interspecific competition as other species utilise warmer areas over the winter months. This may provide an advantage for the northwest Atlantic populations of $N$. brevirostris that are faced with more competitors than those in the Bahamas, so this difference may be beneficial for foraging, growth, and survival. In comparison, $N$. brevirostris at an offshore atoll in Brazil were reported to have faster growth rates than those in the Bahamas (Freitas et al. 2006). Since the atoll lacks the protective cover from predators offered by mangrove habitat, young sharks could have adapted for faster growth in order to reach a size less vulnerable to predation more quickly (Freitas et al. 2006). However, differences in growth rates between regions could also be due to poor habitat quality or decreased resources in the Bahamas, resulting in slower growth. These examples show that the strategy and behaviour a species uses is in part based on its environment. Nearshore areas are not interchangeable but are unique and dynamic systems, which may explain the variety of strategies displayed among shark species.

In addition to shark populations that use nearshore areas frequently and regularly, there are also species that visit these regions on a more occasional basis. Firstly, there are species that tend to have longranging movements and roam far distances offshore such as salmon Lamna ditropis and tiger Galeocerdo cuvier sharks. For example, in the northeast Pacific, L. ditropis moved throughout coastal waters, but also utilised large areas offshore and undertook long distance migrations (Weng et al. 2008). Similarly, in both Shark Bay (Western Australia) and Hawaii, G. cuvier utilised shallow nearshore waters but also displayed large home ranges and frequently moved to deep offshore waters (Holland et al. 1999, Heithaus et al. 2007, Meyer et al. 2009). When G. cuvier were utilising nearshore waters in Hawaii, they undertook a 'coastal patrolling' behaviour and did not remain in one area for a long period of time (Meyer et al. 2009). Secondly, there are species that are typically found in deep water environments offshore such as sixgill Hexanchus griseus and Greenland Somniosus microcephalus sharks. However, Stokesbury et al. (2005) reported S. microcephalus utilising shallow nearshore bays in Canada during the spring and summer months. Similarly, in Puget Sound (USA), juvenile $H$. griseus were found to display short and localised movements close to shore (Andrews et al. 2007). Although these 4 species are examples of sharks that usually undertake longranging movements and/or inhabit deep offshore waters, they also utilise nearshore regions, perhaps for the diverse range of functions and benefits these habitats offer.

\section{HOW SHARK POPULATIONS USE NEARSHORE ENVIRONMENTS}

A variety of ecosystem functions are provided for inhabitants of nearshore areas. Although evidence is scarce, it has been suggested that adult females of some shark species give birth in shallow nearshore waters since neonate individuals are found inhabiting and utilising these regions (Castro 1993). Repeated use of nearshore regions for the purpose of parturition would suggest a successful strategy that increases survival of young. This behaviour promotes population survival and kin selection; adult females presumably expend energy migrating inshore to distinct areas for 
no other reason than to give birth and leave their pups in nearshore regions (Weng et al. 2008), receiving no direct physical benefit themselves. Most animals behave in ways that maximise fitness and strengthen the population as a whole; if giving birth in nearshore regions increases survival of young, this would in turn increase recruitment to the adult population and benefit the entire population, making the energetic investment worthwhile. For some species, nearshore areas may function as critical nursery and pupping habitat. Evidence of philopatry to specific natal nurseries for many years after birth, by both pupping females (Feldheim et al. 2004, Keeney et al. 2005, DiBattista et al. 2008) and juveniles (Hueter et al. 2005, Grubbs et al. 2007), reinforces the important function of nearshore habitat for these species.

Although nearshore nursery areas are used by and contain crucial habitat for some sharks (e.g. species of Springer's hypothetical population), not all species utilise nursery areas and not all nearshore habitats function as nurseries (Heupel et al. 2007). For example, smaller-sized species that represent the second population model (e.g. Atlantic sharpnose Rhizoprionodon terraenovae and blacknose Carcharhinus acronotus sharks) have productive life-histories with rapid growth, early maturity and annual reproduction (Cortés 2002), and do not use discrete nearshore nursery areas (Carlson 2002, Parsons \& Hoffmayer 2005). Rather, smallersized species may use nearshore habitats to exploit prey resources and increase foraging success in order to reach sexual maturity more quickly. Since smallersized species often have productive life-histories and high rates of reproduction, the potential cost of increased mortality in early life-stages from lack of nursery use may be outweighed by the benefit of utilising more resources to promote fast growth. In addition, juveniles of small-sized species may be of a size where they do not receive the same level of protection from nearshore waters than juveniles of large-sized species. For juveniles of small species, predators may include those juveniles of large species using the same areas, so no sufficient protective benefit exists for them to show the same site attachment to specific nursery areas. Thus, nearshore regions may function mostly as productive feeding grounds for these smaller-sized species.

Productive nearshore waters provide a source of food that benefits inhabitants of these areas, but can also be utilised in the short-term by sharks moving in from areas further offshore. As inhabitants, sharks make up a major proportion of predator biomass in nearshore areas, consuming a diverse range and high abundance of the prey available in these environments (Blaber et al. 1989, Stevens \& McLoughlin 1991, Salini et al. 1992). Overlaps in diet have been reported be- tween many of these species (Simpfendorfer \& Milward 1993, Bethea et al. 2004), which suggests that nearshore areas have sufficient productivity to support multiple shark species utilising the same or similar resources. Ontogenetic shifts in diet have also been observed in some species, with adult life-stages consuming larger and/or more diverse prey items (Lowe et al. 1996, Bethea et al. 2006, McElroy et al. 2006). Such shifts in diet might be why adults of larger-sized species roam further distances than juveniles: they may need to expand their range to exploit additional habitats. Nearshore productivity can also be exploited by sharks that occur in these areas only occasionally, and some species move into nearshore regions from areas further offshore to utilise coastal habitats and feed on high quality prey (Heithaus et al. 2002). Diets of shark species vary with geographic location (McElroy et al. 2006), so sharks therefore take advantage of the diversity of resources available to them in the nearshore regions they are utilising.

In addition to parturition, nursery area use and foraging, nearshore regions provide habitat for a variety of other functions. Nearshore waters provide breeding grounds for some shark species, and mature females have also been found to use shallow areas as a refuge to avoid aggressive males and conserve energy during mating season (Pratt \& Carrier 2001, Sims et al. 2001). In addition, for smaller-sized species representative of the second theoretical model, nearshore waters may offer increased protection from predation. For example, Carlson (2002) found a high level of segregation between small-sized species (e.g. Atlantic sharpnose Rhizoprionodon terraenovae, blacknose Carcharhinus acronotus, and bonnethead Sphyrna tiburo sharks) and large-sized species (e.g. blacktip Carcharhinus limbatus and sandbar Carcharhinus plumbeus sharks). Smaller-sized species may segregate from larger-sized species to increase shelter from predation and enhance survival. Shallow nearshore waters also appear to be used for thermoregulation and energy conservation, which is thought to increase metabolic rate, growth, and embryonic development (Economakis \& Lobel 1998, Hight \& Lowe 2007). Overall, nearshore regions serve numerous functions, and utilising nearshore habitats provides multiple advantages and benefits for species success.

\section{LIVING IN NEARSHORE WATERS: CHALLENGES, ADAPTATIONS, AND CONSEQUENCES}

Nearshore environments are characterised by shallow depths with large fluctuations in physical parameters. Thus, there are challenges specific to nearshore waters to which inhabitants must adapt in order 
to remain in these regions. As mobile species, sharks can use conditions to their advantage. For example, juvenile sandbar sharks Carcharhinus plumbeus in the northwest Atlantic moved with tidal flow and showed straightest-line movement during the strongest currents. This behaviour was presumed to minimise energetic costs associated with swimming in strong currents (Medved \& Marshall 1983, Wetherbee \& Rechisky 1999). Leopard sharks Triakis semifasciata in Tomales Bay, California (USA) also utilised tidal fluctuation by moving with incoming tides to exploit food resources in nearshore areas that could otherwise not be reached (Ackerman et al. 2000). In contrast, some changes may force individuals to leave areas. For example, along the west coast of Florida (USA), bonnethead Sphyrna tiburo and young bull Carcharhinus leucas sharks were reported to leave estuaries when salinity declined (Heupel \& Simpfendorfer 2008, Ubeda et al. 2009). Temperature is another factor that affects the distribution of shark species, and the exodus of individuals from nearshore areas has been related to decreasing water temperature (Grubbs et al. 2007, Heupel 2007). Since sharks are highly mobile animals, they are able to move in response to unfavourable changes in their physical environment such as varying salinity or temperature. Although moving to another region when conditions become unfavourable may promote immediate survival, implications arise from relocation and species circumstances may not always be improved. For example, while young C. leucas leaving a nursery to move to an adjacent bay when salinity levels declined reduced the stress of living in a low salinity environment, it also exposed these individuals to potential predation outside the nursery (Simpfendorfer et al. 2005). Displacement from a species' original and/or preferred habitat to other regions may have consequences such as reduced habitat quality, decreased food availability, increased predation risk, or increased competition with other species. However, there may also be consequences if species remain in areas of unfavourable conditions. For example, C. leucas have perished in shallow estuaries during the winter months when water temperature has dropped severely (Snelson \& Bradley 1978). Overall, shark species that inhabit dynamic nearshore areas are faced with many challenges, but high use of these habitats suggests sharks have evolved to derive maximum benefit despite this. For example, Heithaus et al. (2009) found that it was not salinity that influenced the distribution of juvenile C. leucas in a Florida estuary, but rather dissolved oxygen concentrations. Thus, there may be different physical factors that affect species distribution and movement within different regions, and some species appear able to adapt and cope with variable physical conditions within dynamic nearshore environments. However, shark species that are highly dependent on specific habitat and use restricted portions of nearshore areas are probably the most vulnerable when environmental conditions extend beyond their physical limitations.

In addition to seasonal (e.g. temperature) and regular (e.g. tidal) changes, nearshore areas are highly susceptible to sudden events such as storms and weather phenomena that can affect the structure and characteristics of these environments. Species that utilise nearshore waters may either perish in these events or adapt and alter their behaviour to deal with sudden changes. For example, when a tropical storm approached the west coast of Florida (USA), blacktip sharks Carcharhinus limbatus moved from a shallow nursery to the deeper waters of Tampa Bay prior to the storm making landfall (Heupel et al. 2003). Analysis of this event suggested sharks used the corresponding drop in barometric pressure as a cue to leave the bay (Heupel et al. 2003). Presumably individuals moved to avoid storm surge or other adverse conditions produced by severe storm systems, and as such moved to increase survival. However, when an El Niño event occurred off the coast of California (USA), leopard sharks Triakis semifasciata in the region did not leave (Smith \& Abramson 1990). The El Niño event resulted in warm, nutrient-poor water along the California coast, which probably decreased prey quality and availability. The result was a higher fishing mortality of $T$. semifasciata than expected (Smith \& Abramson 1990): this population of $T$. semifasciata may have been more vulnerable to fishing pressure as a result of increased hunger (Stoner 2004). These examples illustrate some of the potential benefits and consequences of moving from, or remaining in, nearshore regions when conditions change.

The final, and potentially most significant, factor in nearshore systems is direct and continuous contact with humans. The close proximity between nearshore waters and humans results in 3 major anthropogenic impacts affecting these areas: (1) habitat degradation due to coastline development and destructive practices, (2) pollution via terrestrial runoff, and (3) exploitation through fisheries.

Coastal development often employs practices such as dredging, construction, and deforestation, all of which have detrimental effects on nearshore environments and can lead to large-scale habitat degradation (van Dolah et al. 1984, Bilkovic \& Roggero 2008). For example, mangrove habitat has declined $35 \%$ worldwide over the past $25 \mathrm{yr}$ as a result of clearing, cutting, and filling for lumber and development (Valiela et al. 2001). Destruction of important and productive habitat can hinder the survival and proliferation of species that use these areas. Jennings et al. (2008) found a 23.5\% 
decline in the survival rate of young lemon sharks Negaprion brevirostris and a related $17.7 \%$ decline in seagrass habitat in the Bahamas, which was a result of increased coastal development. Moreover, other young sharks have appeared emaciated and/or have lost weight while utilising nearshore areas (Lowe 2002, Reyier et al. 2008). Weight loss may be a result of small and inexperienced sharks having low foraging success and increased competition with other species utilising the same areas, or possibly as a result of reduced liver mass as energy reserves are quickly used up after birth (Hussey et al. 2010). However, it is also likely that some nearshore habitats simply no longer contain adequate food sources for the shark species that utilise them, which may be a result of habitat degradation and resource decline due to anthropogenic impacts. Philopatric behaviour patterns may mean sharks continue to return to these areas despite declining conditions.

Increased terrestrial runoff reduces water quality by increasing sedimentation and pollutant levels in nearshore areas (Thrush et al. 2004, Smith et al. 2008). A major consequence of nearshore pollution is eutrophication (Nixon 1995), which reduces oxygen levels, causes declines in the health and overall condition of coastal communities, and affects how species use these environments (Kemp et al. 2005). For example, leopard sharks Triakis semifasciata have been reported to leave nearshore regions during periods of anoxia (Carlisle \& Starr 2009). Pollution has also been reported to lower productivity and damage prey populations within nearshore ecosystems (Thomas \& Seibert 1977, Turley 1999), which may negatively impact the foraging success of sharks that utilise these areas. In addition, some pollutants can have specific implications for species by disrupting biological processes. For example, infertility in bonnethead sharks Sphyrna tiburo has been linked to organochlorines in coastal waters (Gelsleichter et al. 2005). Thus, pollutants and other impacts to water quality may have severe consequences for coastal shark species.

Shark populations are exposed to commercial and recreational fisheries in nearshore areas, with individuals taken as both target species and bycatch. This presents additional challenges for species that utilise nearshore waters as they must be productive enough to withstand fishing pressure. Variations in life-history characteristics result in some species being more resilient to fishing pressure than others (Stevens et al. 2000). Species with slow growth rates and small litter sizes, such as the species of Springer's population model, are generally more vulnerable to fisheries than smaller and more productive species (Smith et al. 1998). Although small and productive species appear to be more resilient, they may still be vulnerable to fishing pressure to some degree. Since smaller-sized species typically reside in nearshore areas for the duration of their life-span, they may encounter numerous coastal fisheries and be caught in higher abundance. For example, in 1995 and 1996, small-sized species made up $72 \%$ of total shark catch in fishing surveys conducted in the Gulf of Mexico and northwest Atlantic, with similar numbers being reported in commercial fishing activities (Grace \& Henwood 1997). Moreover, young sharks that use discrete nursery areas and small core areas of space may be susceptible to a direct and localised fishery. In an example from a bay where fishing occurred, natural and fishing mortalities in a population of young blacktip sharks Carcharhinus limbatus were estimated to be 32 to $70 \%$ and 41 to $60 \%$ respectively, resulting in a high total mortality of 61 to $91 \%$ (Heupel \& Simpfendorfer 2002). In contrast, in areas where fishing was negligible, a population of young lemon sharks Negaprion brevirostris was only affected by natural mortality, and mortality here was estimated to be just 44 to $61 \%$ (Manire $\&$ Gruber 1993). Fishing pressure is not a physical variable that sharks can respond to by leaving an area when conditions become unfavourable, such as how they might respond to changes in temperature or salinity: if a shark leaves an area where fishing occurs, it is likely that it will enter another. The consequence of fisheries in nearshore waters is that species living there have a greater chance of being overfished without careful management. Surviving exploitation from fishing pressure is a challenge for many species and is an additional impact on shark populations using easily accessed nearshore regions.

The newly proposed model for coastal shark populations remaining in nearshore areas through most of their life-cycle has implications for understanding the effects of humans. Since all age-classes of these populations may inhabit 1 specific nearshore area, an entire population will be highly vulnerable if a direct impact occurs there. Unlike the species that fit Springer's population model, there is no age refuge for these smallersized species. For example, it is possible for a coastal fishery (commercial and/or recreational) to land all age-classes of smaller-sized shark species inhabiting 1 area, resulting in a higher negative effect on these populations compared to the populations whose juveniles only occur nearshore. However, implementation of certain management initiatives such as marine park areas (MPAs) may be effective in protecting smallsized species that show site attachment and use restricted portions of nearshore areas. Although MPAs may be successful in protecting some of these smallsized species, they will probably be less effective for those that tend to have a roaming behaviour. It is important to identify these additional population models that address the differences in life-history and 
behavioural characteristics of coastal shark species so this information can be included in conservation and management planning.

\section{CONCLUSIONS}

Springer (1967) presented a model explaining the distribution of a hypothetical shark population and this description fits some species well. These are generally larger-sized species that use restricted portions of nearshore regions for short periods during their early life-stages, which suggests that nearshore waters contain important habitat and act as nurseries for the young of these species. However, a second and alternative population model is proposed in this paper, representing species that are typically smaller-sized. Individuals of these species inhabit nearshore waters for their entire life-cycle and generally utilise larger amounts of space, which implies they may be more dependent on nearshore habitats but are perhaps less reliant on specific areas. The strategies of these 2 population models are based on both life-history characteristics and environmental conditions. However, nearshore environments are highly dynamic and species distribution and habitat use may vary between regions. Thus, not all populations fit these models and exceptions to these models do exist.

Since nearshore waters are typically shallow and immediately adjacent to land, they are commonly susceptible to environmental change, many types of exploitation, and human impacts. Thus, nearshore areas present a potentially taxing environment with highly dynamic conditions continually challenging inhabitants, but high use of these areas implies sharks are relatively tolerant of variable environments. In order to survive, species must cope, adapt accordingly, or leave when conditions become unfavourable. Due to their mobility, sharks can use these regions as needed and leave if conditions decline. However, leaving does not always guarantee survival and other costs may arise from moving to different, possibly less optimal, habitat.

Overall, nearshore regions are highly productive and offer a wide variety of habitat types for shark species. Nearshore waters provide many functions that are advantageous, with sharks using regions as nursery areas, refuge from predators, and foraging and mating grounds. Understanding differences in distribution and habitat use between shark species that utilise nearshore waters will help define differences in behaviour that may result in varying implications for different species. For example, an area that is subject to a localised disturbance could have severe consequences for a species using a restricted area, while a wide-ranging species using large areas may be less affected, being less dependent on the disturbed area. Thus, nearshore habitats have varying levels of importance for different species. It is important to distinguish and understand the differences in distribution and habitat use between shark species in nearshore areas to conserve important habitat and enhance the success of populations that utilise these regions.

\section{LITERATURE CITED}

Abel DC, Young RF, Garwood JA, Travaline MJ, Yednock BK (2007) Survey of the shark fauna in two South Carolina estuaries and the impact of salinity structure. Am Fish Soc Symp 50:109-124

Ackerman JT, Kondratieff MC, Matern SA, Joseph J, Cech J (2000) Tidal influence on spatial dynamics of leopard sharks, Triakis semifasciata, in Tomales Bay, California. Environ Biol Fishes 58:33-43

Andrews KS, Levin PS, Katz SL, Farrer D, Gallucci VF, Bargmann G (2007) Acoustic monitoring of sixgill shark movements in Puget Sound: evidence for localized movement. Can J Zool 85:1136-1142

$>$ Beck MW, Heck KL, Able KW, Childers DL and 9 others (2001) The identification, conservation, and management of estuarine and marine nurseries for fish and invertebrates. BioScience 51:633-641

Bethea DM, Buckel JA, Carlson JK (2004) Foraging ecology of the early life stages of four sympatric shark species. Mar Ecol Prog Ser 268:245-264

Bethea DM, Carlson JK, Buckel JA, Satterwhite M (2006) Ontogenetic and site-related trends in the diet of the Atlantic sharpnose shark Rhizoprionodon terraenovae from the northeast Gulf of Mexico. Bull Mar Sci 78:287-307

Bigelow HB, Schroeder WC (1948) Sharks. In: Fishes of the Western North Atlantic, Part 1. Memoir Sears Foundation for Marine Research, p 59-546

Bilkovic DM, Roggero MM (2008) Effects of coastal development on nearshore estuarine nekton communities. Mar Ecol Prog Ser 358:27-39

Blaber SJM, Brewer DT, Salini JP (1989) Species composition and biomasses of fishes in different habitats of a tropical northern Australian estuary: their occurrence in the adjoining sea and estuarine dependence. Estuar Coast Shelf Sci 29:509-531

Branstetter S (1990) Early life-history implications of selected Carcharhinoid and Lamnoid sharks of the northwest Atlantic. NOAA Tech Rep NMFS 90:17-28

> Carlisle AB, Starr RM (2009) Habitat use, residency, and seasonal distribution of female leopard sharks Triakis semifasciata in Elkhorn Slough, California. Mar Ecol Prog Ser 380:213-228

Carlson JK (2002) Shark nurseries in the northeastern Gulf of Mexico. In: McCandless CT, Pratt HL Jr, Kohler NE (eds) Shark nursery grounds of the Gulf of Mexico and east coast waters of the United States: an overview. An internal report to NOAA's Highly Migratory Species Office. NOAA Fisheries, Narragansett, RI, p 165-182

Carlson JK, Heupel MR, Bethea DM, Hollensead LD (2008) Coastal habitat use and residency of juvenile Atlantic sharpnose sharks (Rhizoprionodon terraenovae). Estuaries Coasts 31:931-940

> Castro JI (1993) The shark nursery of Bulls Bay, South Carolina, with a review of the shark nurseries of the southeastern coast of the United States. Environ Biol Fishes 38: $37-48$ 
Castro JI (1996) Biology of the blacktip shark, Carcharhinus limbatus, off the southeastern United States. Bull Mar Sci 59:508-522

Compagno LJV (1984) FAO species catalogue, Volume 4. Sharks of the world; an annotated and illustrated catalogue of shark species known to date. Part 2. Carcharhiniformes. FAO Fish Synop 125:251-655

Conrath CL, Musick JA (2008) Investigations into depth and temperature habitat utilization and overwintering grounds of juvenile sandbar sharks, Carcharhinus plumbeus: the importance of near shore North Carolina waters. Environ Biol Fishes 82:123-131

Costanza R, d'Arge R, de Groot R, Farber S and others (1997) The value of the world's ecosystem services and natural capital. Nature 387:253-260

> Cortés E (1999) Standardized diet compositions and trophic levels of sharks. ICES J Mar Sci 56:707-717

Cortés E (2000) Life history patterns and correlations in sharks. Rev Fish Sci 8:299-344

> Cortés E (2002) Incorporating uncertainty into demographic modeling: application to shark populations and their conservation. Conserv Biol 16:1048-1062

> DeAngelis BM, McCandless CT, Kohler NE, Recksiek CW, Skomal GB (2008) First characterization of shark nursery habitat in the United States Virgin Islands: evidence of habitat partitioning by two shark species. Mar Ecol Prog Ser 358:257-271

> DeMaster DP, Fowler CW, Perry SL, Richlen ME (2001) Predation and competition: the impact of fisheries on marinemammal populations over the next one hundred years. J Mammal 82:641-651

> DiBattista JD, Feldheim KA, Thibert-Plante X, Gruber SH, Hendry AP (2008) A genetic assessment of polyandry and breeding-site fidelity in lemon sharks. Mol Ecol 17: $3337-3351$

Economakis AE, Lobel PS (1998) Aggregation behavior of the grey reef shark, Carcharhinus amblyrhynchos, at Johnston Atoll, central Pacific Ocean. Environ Biol Fishes 51: 129-139

Feldheim KA, Gruber SH, Ashley MV (2004) Reconstruction of parental microsatellite genotypes reveals female polyandry and philopatry in the lemon shark, Negaprion brevirostris. Evolution 58:2332-2342

Francis MP (1998) New Zealand shark fisheries: development, size and management. Mar Freshw Res 49:579-591

- Freitas RHA, Rosa RS, Gruber SH, Wetherbee BM (2006) Early growth and juvenile population structure of lemon sharks Negaprion brevirostris in the Atol das Rocas Biological Reserve, off north-east Brazil. J Fish Biol 68: 1319-1332

Gelsleichter J, Manire CA, Szabo NJ, Cortés E, Carlson J, Lombardi-Carlson L (2005) organochlorine concentrations in bonnethead sharks (Sphyrna tiburo) from four Florida estuaries. Arch Environ Contam Toxicol 48:474-483

Grace M, Henwood T (1997) Assessment of the distribution and abundance of coastal sharks in the U.S. Gulf of Mexico and Eastern Seaboard, 1995 and 1996. Mar Fish Rev 59:23-32

Grubbs RD, Musick JA, Conrath CL, Romine JG (2007) Longterm movements, migration and temporal delineation of a summer nursery for juvenile sandbar sharks in the Chesapeake Bay region. Am Fish Soc Symp 50:87-107

- Heithaus MR, Dill LM, Marshall GJ, Buhleier BM (2002) Habitat use and foraging behaviour of tiger sharks (Galeocerdo cuvier) in a seagrass ecosystem. Mar Biol 140:237-248

Heithaus MR, Wirsing AJ, Dill LM, Heithaus LI (2007) Longterm movements of tiger sharks satellite-tagged in Shark Bay, Western Australia. Mar Biol 151:1455-1461
Heithaus MR, Frid A, Wirsing AJ, Worm B (2008) Predicting ecological consequences of marine top predator declines. Trends Ecol Evol 23:202-210

Heithaus MR, Delius BK, Wirsing AJ, Dunphy-Daly MM (2009) Physical factors influencing the distribution of a top predator in a subtropical oligotrophic estuary. Limnol Oceanogr 54:472-482

Heupel MR (2007) Exiting Terra Ceia Bay: an examination of cues stimulating migration from a summer nursery area. Am Fish Soc Symp 50:265-280

Heupel MR, Hueter RE (2001) Use of an automated acoustic telemetry system to passively track juvenile blacktip shark movements. In: Sibert JR, Nielsen JL (eds) Electronic tagging and tracking in marine fisheries. Kluwer Academic Publishers, Dordrecht, p 217-236

Heupel MR, Simpfendorfer CA (2002) Estimation of mortality of juvenile blacktip sharks, Carcharhinus limbatus, within a nursery area using telemetry data. Can J Fish Aquat Sci 59:624-632

> Heupel MR, Simpfendorfer CA (2008) Movement and distribution of young bull sharks Carcharhinus leucas in a variable estuarine environment. Aquat Biol 1:277-289

> Heupel MR, Simpfendorfer CA, Hueter RE (2003) Running before the storm: blacktip sharks respond to falling barometric pressure associated with Tropical Storm Gabrielle. J Fish Biol 63:1357-1363

> Heupel MR, Simpfendorfer CA, Hueter RE (2004) Estimation of shark home ranges using passive monitoring techniques. Environ Biol Fishes 71:135-142

> Heupel MR, Simpfendorfer CA, Collins AB, Tyminski JP (2006) Residency and movement patterns of bonnethead sharks, Sphyrna tiburo, in a large Florida estuary. Environ Biol Fishes 76:47-67

> Heupel MR, Carlson JK, Simpfendorfer CA (2007) Shark nursery areas: concepts, definition, characterization and assumptions. Mar Ecol Prog Ser 337:287-297

> Hight BV, Lowe CG (2007) Elevated body temperatures of adult female leopard sharks, Triakis semifasciata, while aggregating in shallow nearshore embayments: evidence for behavioral thermoregulation? J Exp Mar Biol Ecol 352: $114-128$

Holland KN, Wetherbee BM, Lowe CG, Meyer CG (1999) Movements of tiger sharks (Galeocerdo cuvier) in coastal Hawaiian waters. Mar Biol 134:665-673

Hueter RE, Heupel MR, Heist EJ, Keeney DB (2005) Evidence of philopatry in sharks and implications for the management of shark fisheries. J Northwest Atl Fish Sci 35: 239-247

Hussey NE, Wintner SP, Dudley SFJ, Cliff G, Cocks DT, MacNeil MA (2010) Maternal investment and size-specific reproductive output in carcharhinid sharks. J Anim Ecol 79:184-193

Jackson JBC, Kirby MX, Berger WH, Bjorndal KA and others (2001) Historical overfishing and the recent collapse of coastal ecosystems. Science 293:629-638

Jennings DE, Gruber SH, Franks BR, Kessel ST, Robertson AL (2008) Effects of large-scale anthropogenic development on juvenile lemon shark (Negaprion brevirostris) populations of Bimini, Bahamas. Environ Biol Fishes 83:369-377

Keeney DB, Heupel MR, Hueter RE, Heist J (2005) Microsatellite and mitochondrial DNA analyses of the genetic structure of blacktip shark (Carcharhinus limbatus) nurseries in the northwestern Atlantic, Gulf of Mexico, and Caribbean Sea. Mol Ecol 14:1911-1923

Kemp WM, Boynton WR, Adolf JE, Boesch DF and others (2005) Eutrophication of Chesapeake Bay: historical trends and ecological interactions. Mar Ecol Prog Ser 303:1-29 
Klimley AP (1987) The determinants of sexual segregation in the scalloped hammerhead shark, Sphyrna lewini. Environ Biol Fishes 18:27-40

Last PR, Stevens JD (2009) Sharks and rays of Australia, 2nd edn. CSIRO Division of Fisheries, Cronulla

Lowe CG (2002) Bioenergetics of free-ranging juvenile scalloped hammerhead sharks (Sphyrna lewini) in Kane'ohe Bay, O'ahu, HI. J Exp Mar Biol Ecol 278:141-156

Lowe CG, Wetherbee BM, Crow GL, Tester AL (1996) Ontogenetic dietary shifts and feeding behavior of the tiger shark, Galeocerdo cuvier, in Hawaiian waters. Environ Biol Fishes 47:203-211

Manire CA, Gruber SH (1993) A preliminary estimate of natural mortality of age-0 lemon sharks, Negaprion brevirostris. NOAA Tech Rep NMFS 115:65-71

Mann KH (2000) Ecology of coastal waters with implications for management. Blackwell Science, Malden, MA

Masselink G, Austin M, Tinker J, O'Hare T, Russell P (2008) Cross-shore sediment transport and morphological response on a macrotidal beach with intertidal bar morphology, Truc Vert, France. Mar Geol 251:141-155

McAuley RB, Simpfendorfer CA, Hyndes GA, Lenanton RCJ (2007) Distribution and reproductive biology of the sandbar shark, Carcharhinus plumbeus (Nardo), in Western Australian waters. Mar Freshw Res 58:116-126

McElroy WD, Wetherbee BM, Mostello CS, Lowe CG, Crow GL, Wass RC (2006) Food habits and ontogenetic changes in the diet of the sandbar shark, Carcharhinus plumbeus, in Hawaii. Environ Biol Fishes 76:81-92

Medved RJ, Marshall JA (1983) Short term movements of young sandbar sharks, Carcharhinus plumbeus (Pisces, Carcharhinidae). Bull Mar Sci 33:87-93

- Merson RR, Pratt HL Jr (2001) Distribution, movements and growth of young sandbar sharks, Carcharhinus plumbeus, in the nursery grounds of Delaware Bay. Environ Biol Fishes 61:13-24

> Meyer CG, Clark TB, Papastamatiou YP, Whitney NM, Holland KN (2009) Long-term movement patterns of tiger sharks Galeocerdo cuvier in Hawaii. Mar Ecol Prog Ser 381:223-235

> Mol JH, Resida D, Ramlal JS, Becker CR (2000) Effects of El niño-related drought on freshwater and brackish-water fishes in Suriname, South America. Environ Biol Fishes 59:429-440

Morin B, Hudon C, Whoriskey FG (1992) Environmental influences on seasonal distribution of coastal and estuarine fish assemblages at Wemindji, eastern James Bay. Environ Biol Fishes 35:219-229

Morrissey JF, Gruber SH (1993a) Home range of juvenile lemon sharks, Negaprion brevirostris. Copeia 1993: 425-434

Morrissey JF, Gruber SH (1993b) Habitat selection by juvenile lemon sharks, Negaprion brevirostris. Environ Biol Fishes 38:311-319

Nixon SW (1995) Coastal marine eutrophication-a definition, social causes, and future concerns. Ophelia 41:199-219

> Parsons GR, Hoffmayer ER (2005) Seasonal changes in the distribution and relative abundance of the Atlantic sharpnose shark Rhizoprionodon terraenovae in the north central Gulf of Mexico. Copeia 4:914-920

Pauly D, Christensen V, Dalsgaard J, Froese R, Torres F (1998) Fishing down marine food webs. Science 279: 860-863

Pikitch EK, Chapman DD, Babcock EA, Shivji MS (2005) Habitat use and demographic population structure of elasmobranchs at a Caribbean atoll (Glover's Reef, Belize). Mar Ecol Prog Ser 302:187-197
Pradervand F, Mann BQ, Bellis MF (2007) Long-term trends in the competitive shore fishery along the KwaZulu-Natal coast, South Africa. Afr Zool 42:216-236

Pratt HL Jr, Carrier JC (2001) A review of elasmobranch reproductive behavior with a case study on the nurse shark, Ginglymostoma cirratum. Environ Biol Fishes 60: 157-188

Reyier EA, Adams DH, Lowers RH (2008) First evidence of a high density nursery ground for the lemon shark, Negaprion brevirostris, near Cape Canaveral, Florida. Fla Sci 71:134-148

> Robertson AI, Duke NC (1987) Mangroves as nursery sites: comparisons of the abundance and species composition of fish and crustaceans in mangroves and other nearshore habitats in tropical Australia. Mar Biol 96:193-205

Rodriguez RW, Webb RMT, Bush DM (1994) Another look at the impact of hurricane Hugo on the shelf and coastal resources of Puerto Rico, USA. J Coast Res 10:278-296

Salini JP, Blaber SJM, Brewer DT (1992) Diets of sharks from estuaries and adjacent waters of the northeastern Gulf of Carpentaria, Australia. Aust J Mar Freshw Res 43:87-96

Simpfendorfer CA, Milward NE (1993) Utilisation of a tropical bay as a nursery area by sharks of the families Carcharhinidae and Sphyrnidae. Environ Biol Fishes 37:337-345

> Simpfendorfer CA, Freitas GF, Wiley TR, Heupel MR (2005) Distribution and habitat partitioning of immature bull sharks (Carcharhinus leucas) in a Southwest Florida Estuary. Estuaries 28:78-85

> Sims DW (2003) Tractable models for testing theories about natural strategies: foraging behaviour and habitat selection of free-ranging sharks. J Fish Biol 63:53-73

> Sims DW, Nash JP, Morritt D (2001) Movements and activity of male and female dogfish in a tidal sea lough: alternative behavioural strategies and apparent sexual segregation. Mar Biol 139:1165-1175

Smith SE, Abramson NJ (1990) Leopard shark Triakis semifasciata distribution, mortality rate, yield, and stock replenishment estimates based on a tagging study in San Francisco Bay. Fish Bull 88:371-381

Smith SE, Au DW, Show C (1998) Intrinsic rebound potentials of 26 species of Pacific sharks. Mar Freshw Res 49:663-678

Smith SDA, Rule MJ, Harrison M, Dalton SJ (2008) Monitoring the sea change: preliminary assessment of the conservation value of nearshore reefs, and existing impacts, in a high-growth, coastal region of subtropical eastern Australia. Mar Pollut Bull 56:525-534

Snelson FF, Bradley WK (1978) Mortality of fishes due to cold on the east coast of Florida, January, 1977. Fla Sci 41:1-12

Springer S (1950) Natural history notes on the lemon shark, Negaprion brevirostris. Tex J Sci 2:349-359

Springer S (1960) Natural history of the sandbar shark, Eulamia milberti. Fish Bull 61:1-38

Springer S (1967) Social organisation of shark populations. In: Gilbert PW, Matheson RF, Rall DP (eds) Sharks, skates and rays. John Hopkins Press, Baltimore, MD, p 149-174

Stevens JD, McLoughlin KJ (1991) Distribution, size and sex composition, reproductive biology and diet of sharks from Northern Australia. Aust J Mar Freshw Res 42:151-199

Stevens JD, Bonfil R, Dulvy NK, Walker PA (2000) The effects of fishing on sharks, rays, and chimaeras (chondrichthyans), and the implications for marine ecosystems. ICES J Mar Sci 57:476-494

> Stokesbury MJW, Harvey-Clark C, Gallant J, Block BA, Myers RA (2005) Movement and environmental preferences of Greenland sharks (Somniosus microcephalus) electronically tagged in the St. Lawrence Estuary, Canada. Mar Biol 148:159-165 
Stoner AW (2004) Effects of environmental variables on fish feeding ecology: implications for the performance of baited fishing gear and stock assessment. J Fish Biol 65: 1445-1471

Suchanek TH (1994) Temperate coastal marine communities-biodiversity and threats. Am Zool 34:100-114

Thomas WH, Seibert DLR (1977) Effects of copper on dominance and diversity of algae-controlled ecosystem pollution experiment. Bull Mar Sci 27:23-33

Thrush SF, Hewitt JE, Cummings V, Ellis JI, Hatton C, Lohrer A, Norkko A (2004) Muddy waters: elevating sediment input to coastal and estuarine habitats. Front Ecol Environ 2:299-306

Turley CM (1999) The changing Mediterranean Sea-a sensitive ecosystem? Prog Oceanogr 44:387-400

- Ubeda AJ, Simpfendorfer CA, Heupel MR (2009) Movements of bonnetheads, Sphyrna tiburo, as a response to salinity change in a Florida estuary. Environ Biol Fishes 84: 293-303

Ulrich GF, Jones CM, Driggers WB III, Drymon JM, Oakley D, Riley C (2007) Habitat utilization, relative abundance, and seasonality of sharks in the estuarine and nearshore waters of South Carolina. Am Fish Soc Symp 50:125-139

Valiela I, Bowen JL, York JK (2001) Mangrove forests: one of the world's threatened major tropical environments. BioScience 51:807-815

van Dolah RF, Calder DR, Knott DM (1984) Effects of dredging and open water disposal on benthic macroinvertebrates in a South Carolina estuary. Estuaries 7:28-37

Vitousek PM, Mooney HA, Lubchenco J, Melillo JM (1997)

Editorial responsibility: Otto Kinne,

Oldendorf/Luhe, Germany
Human domination of earth's ecosystems. Science 277: 494-499

Walker TI (1998) Can shark resources be harvested sustainably? A question revisited with a review of shark fisheries. Mar Freshw Res 49:553-572

Weng KC, Foley DG, Ganong JE, Perle C, Shillinger GL, Block BA (2008) Migration of an upper trophic level predator, the salmon shark Lamna ditropis, between distant ecoregions. Mar Ecol Prog Ser 372:253-264

Wetherbee BM, Rechisky EL (1999) Movement patterns of juvenile sandbar sharks on their nursery grounds in Delaware Bay. In: Eiler JH, Alcorn DJ, Neuman MR (eds) Biotelemetry 15: Proc 15th Int Symp Biotelemetry. International Society on Biotelemetry, Wageningen, p 91-98

Wetherbee BM, Crow GL, Lowe CG (1996) Biology of the Galapagos shark, Carcharhinus galapagensis, in Hawai'i. Mar Biol 45:299-310

Wetherbee BM, Rechisky EL, Pratt HL Jr, McCandless CT (2001) Use of telemetry in fisheries management: juvenile sandbar sharks in Delaware Bay. In: Sibert JR, Nielsen JL (eds) Electronic tagging and tracking in marine fisheries. Kluwer Academic Publishers, Dordrecht, p 249-262

> Wetherbee BM, Gruber SH, Rosa RS (2007) Movement patterns of juvenile lemon sharks Negaprion brevirostris within Atol das Rocas, Brazil: a nursery characterized by tidal extremes. Mar Ecol Prog Ser 343:283-293

> White WT, Potter IC (2004) Habitat partitioning among four elasmobranch species in nearshore, shallow waters of a subtropical embayment in Western Australia. Mar Biol 145:1023-1032

Submitted: October 3, 2009; Accepted: January 18, 2010

Proofs received from author(s): March 2, 2010 